\title{
American Strategy in the Far East
}

HARRY HARDING

American strategy in the Far East - or, as we are increasingly accustomed to calling it, East Asia or the Asia-Pacific region - is an extremely complex topic that is difficult to summarize in a balanced and comprehensive way in a brief lecture.

The difficulty of the subject stems first of all from the complexity of the Asia-Pacific region. As commonly defined in the United States, East Asia includes more than thirty countries and regions, of diverse size, location, population, level of development, and political system. Geographically, the region extends from Siberia in the north to New Zealand in the south, and from Tibet in the west to Samoa in the east. In size, the nations of East Asia range from vast continental nations such as the Soviet Union, to large island archipelagos like Japan and Indonesia, to small city states such as Singapore. In population, they include both China, with its billion people, and the island nations of the South Pacific, with populations of only several thousands. The Asia-Pacific region comprises not only the postindustrial economy of Japan and the newly-industrialized economies of South Korea and Taiwan, but also dynamic exporters of primary products, such as Indonesia and Thailand, and some of the poorest nations in the world, including Laos and Burma. Politically, the countries of the region range from industrial democracies (such as Japan) to some of the most despotic totalitarian systems (such as North Korea), as well as quasi-democracies, military authoritarian systems, and even a few colonies (such as Hong Kong, Macao, and New Caledonia). In short, compared with Europe - or even with Africa or Latin America - East Asia is a more diverse and expansive region. Accordingly, American policy there must also be differentiated and complex.

Secondly, the complexity of the subject of this lecture results from the fact that American policy toward the Asia-Pacific region is increasingly multidimensional. In the past, an assessment of American relations with East Asia could reasonably focus exclusively on matters of diplomacy, politics, and strategy, setting economic questions safely aside. Such an approach would be unthinkable today. Although there are still important political and strategic elements in American relations with the Asia-Pacific nations, economics has 
increasingly come to occupy the highest position on the American agenda in the region. Indeed, it is now the most important issue in American relations with the majority of the countries of East Asia, including not only Japan, but also China, Taiwan, South Korea, and most of Southeast Asia.

These complexities make it inevitable that this lecture be somewhat superficial and simplistic. Nonetheless, it is intended to provide a broad overview of the major American objectives in the Asia-Pacific region since the end of World War II, and the evolving American strategies in pursuing those goals. American policy in East Asia over the last forty years has revolved around four principal interests, which have given a degree of continuity to American relations with the region. These include:

- 1) an interest in maintaining a stable balance of power in the region as a whole and, more particularly, in containing the expansion of the Soviet Union;

- 2) a related interest in ensuring peace and stability in a number of local disputes in the region, especially those involving the Korean peninsula, Taiwan, and Indochina;

- 3) an interest in the economic prosperity of the region, and in promoting mutually beneficial economic relations between the Asia-Pacific economies and that of the United States;

- 4) an interest in encouraging progress toward political liberalization and institutionalization in the dynamic states of the region.

After reviewing these four goals, and the changing strategies employed to achieve them, I want to look forward a bit, to suggest the new challenges and opportunities facing the United States in East Asia as we gradually enter what I believe will be a new era in the Asia-Pacific region.

\section{Containing the Soviet Union}

From a strategic perspective, containment of the Soviet Union, which can be defined as maintaining a favorable global balance of power relative to the Soviet Union, has been the central component of American foreign policy throughout the world since the late 1940s. Ironically, this strategy was applied to Asia only in an indirect sense during most of the postwar period. Until the late 1960s, the Soviet Union devoted relatively little of its diplomatic and military resources to the Asian-Pacific region. As a result, American 
containment strategies in the region focussed not so much on the Soviet Union itself, as on those Communist nations that were regarded in Washington as extensions of Soviet influence: North Korea, China, and North Vietnam.

Since the late 1960s, however, the Asia-Pacific region has witnessed a vast expansion of Soviet military power. The build-up began, to be sure, largely as a response to the intensification of the Sino-Soviet border dispute, but it soon became linked to Moscow's global competition with the United States as well. The growth of Soviet forces in the Far East has now developed to the point that around one-third of the Soviet naval and air forces, and about onequarter of its ground forces, are stationed in East Asia, and are equipped with some of the most modern equipment that Moscow's arsenals can provide. The Soviet Union has taken over the former American base in Cam Ranh Bay in Vietnam, and has even enlarged it considerably. The increasing scale and sophistication of Soviet military exercises, and particularly the use of Soviet forces in Afghanistan since 1980 and against the ill-fated Korean airliner in 1983, have demonstrated that Moscow is prepared to employ its new military resources in the Asia-Pacific region in the pursuit of its national objectives.

Although the quantitative dimension of the Soviet military build-up is widely accepted, there is considerable debate in the United States over its goal and missions. Virtually all analysts agree that Soviet forces are intended to undertake important defensive and deterrent assignments: to defend Siberia against any Chinese incursion, to deter Peking against any large-scale military action against Vietnam, to deploy a strategic nuclear submarine force from Vladivostok and Petropavlask, and to defend those bases against any American attack. Further, the expansion of Soviet military forces is clearly defined to establish Moscow as a major regional power, and thus to compensate for the Kremlin's present lack of effective economic, diplomatic, or cultural resources in the Asia-Pacific region.

Beyond this, some analysts believe that there are additional offensive motivations behind the Soviet military build-up. It is not considered likely that the Soviet Union would choose to launch a major conflict in the AsiaPacific region. Should a conventional global war begin elsewhere, however, the Soviet Union might decide to use its forces in the Far East to seize parts of China or Japan, in part to ensure its own defence, and partially to obtain leverage in any negotiations to end the conflict. The Soviet Union might also wish to interdict the sea lines of communication between Japan and the 
Middle East or between Japan and the United States, or to attack American military installations in the Asia-Pacific region.

The American response to recent Soviet military deployments has contained three main components. First, the United States has provided its own forces in the Pacific with improved weapons: F-16s, Tomahawk cruise missiles, Trident submarines, a seventh aircraft carrier task force, and new frigates and destroyer escorts. Under its former Secretary, John Lehman, the Department of the Navy began developing a strategy of "horizontal escalation", under which naval task forces could undertake counter-offensive operations against vulnerable areas of the Soviet Union in the event of a general war. The Northwest Pacific, and particularly the so-called "ocean bastion" of the Sea of Okhotsk, was widely regarded as one of the areas in which this "maritime strategy" would most likely be applied.

Second, the United States has attempted to strengthen its strategic cooperation with other friendly countries in the region. For example, the United States is now engaged with China in regular consultation and dialogue on regional issues, sharing of intelligence, exchanges of military personnel, and limited sales of defensive military equipment. The recent visit by an American naval flotilla to Qingdao, and the subsequent performance in China by the precision flying team of the American air force, symbolize the growing ties between the military establishments of the two countries. In the case of Japan, Washington and Tokyo now undertake more detailed and comprehensive coordination of their national defence strategies, conduct larger and more effective joint military exercises, and cooperate in the development of certain types of military technology.

To a degree, these developments reflect an American effort to shift part of the burden of regional security to some of the more prosperous countries in the area that can well afford to bear it. We have encouraged the Japanese to spend more money on, and to assume a greater responsibility for, their own defence. There are indications that a similar policy will be undertaken toward South Korea in a few years' time. In neither case, however, is the United States proposing to abandon its treaty commitments to its partner, or to force it to accept complete responsibility for its own security. Rather, it is attempting to allocate the burdens of regional security more rationally, at a time when American economic preeminence is waning, and when other parts of the world compete for American attention and resources.

Third, the United States has successfully engaged in negotiations with the Soviet Union to limit the number of intermediate-range nuclear forces (INF) 
deployed in East Asia, as well as those stationed in Europe. At every stage, Washington took into account the interests of its allies in Tokyo and Peking. When the negotiations began, Washington insisted that any Soviet SS-20s removed from Europe as the result of an INF agreement be detroyed, rather than redeployed to East Asia. Later, the United States resisted a formula that would have allowed the two superpowers to retain one hundred INF warheads in the Asia-Pacific region, while removing all such weapons from the European theater. Instead, Washington won Soviet acceptance of a global "double-zero" formula, under which all INF systems, in both Europe and Asia, will be dismantled. It is not inconceivable that the two superpowers will also undertake further negotiations on conventional arms control and confidence building measures in the Asia-Pacific region.

This tripartite strategy has introduced some strains into America's relations with some friendly Asian countries. Not all Asian nations share the same perceptions of the Soviet threat as the United States. Some, particularly those distant from the Soviet Union, take a less alarmist view of Moscow's capabilities and intentions than is common in Washington; others, particularly in Southeast Asia, are more concerned with the long-run threat from China or Japan than with the immediate challenge of the Soviet Union. As a result, there is a widespread and understandable concern that the United States, in its attempt to "share the burden" with others, will promote a level of armament in China or Japan that will later have destabilizing consequences for the rest of the region.

In addition, there has been growing apprehension among some American allies that they risk preemptive or retalitatory action from the Soviet Union if they maintain a security relationship with the United States. Relatedly, there is also worry about the implications of the arms race that the two superpowers have been conducting in the Northwest Pacific over the last decade. Together, these concerns have produced a growing nuclear allergy in the area, and a desire for insulation from the strategic competition between the United States and the Soviet Union. These sentiments can be seen most plainly in New Zealand, whose government has prohibited nuclear-armed or nuclear-powered American vessels from entering the country's ports, and which has therefore seen its alliance with the United States effectively suspended. But similar views can also be heard in some quarters in the South Pacific and Southeast Asia (where there is continuing pressure for the creation of subregional nuclear-free zones), and in the Philippines, Japan, and even South Korea (where there is concern that the presence of American 
bases makes those countries likely targets for Soviet attack in the event of a general war).

Moreover, the United States now faces in Mikhail Gorbachev a more flexible adversary than in the past. It is clear that Gorbachev assigns a much higher priority to Soviet relations with East Asia than did his predecessors, and that he is aware that the Kremlin's nearly exclusive emphasis on the development of its military power has alienated the Soviet Union from the majority of the countries in the region. Since his major speech on Asian issues in Vladivostok in July 1986, therefore, Gorbachev has made some substantive overtures toward China, has avidly courted the North Koreans, and has adopted a more subtle and flexible strategy toward Japan and the non-Communist states of Southeast Asia. Some Soviet allies, notably Laos and Mongolia, have also been encouraged to engage in similar démarches to former adversaries. The Kremlin has identified some of the issues on which the United States is most vulnerable - including the strains in its economic relations with several Asian countries, the nuclear allergy mentioned above, and the concern about the naval arms race in the region - and is attempting to find ways of capitalizing on them.

All this implies that the United States, too, will have to be more flexible and sophisticated in its Asian strategy. No longer can it count on Soviet indifference or insensitivity. No longer can it assume that its security relations with the rest of the region will rest on a solid and mutually satisfactory economic base. Increasingly, Washington will have to devise common strategic perceptions and policies through dialogue and consultation with its friends and allies in the Asia-Pacific region, rather than by attempting to impose them unilaterally.

\section{Regional disputes}

Ever since 1950, the United States has had a continuing involvement in three local disputes in the Asia-Pacific region: Korea, Taiwan, and Indochina. In each case, we have employed military force to help protect the nonCommunist territory with which we have been allied from its Communist neighbor: we helped defend South Korea against the North in 1950, participated in two crises over the Chinese offshore islands in 1954-55 and 1958, and engaged in a costly and protracted war in Vietnam between 1964 and 1975. Moreover, the United States maintains an interest in all three of 
these conflicts. We have a mutual defence treaty with South Korea, and have 40.000 troops stationed there. Although we have normalized our relations with China, we have frenquently reiterated our interest in a peaceful resolution of the Taiwan question, and continue to sell a limited amount of defensive weapons to Taipei. Finally, even though the Southeast Asian Treaty Organization is no longer in operation, we retain our treaty commitments to the security of Thailand, and have consistently expressed our opposition to the Vietnamese invasion of Cambodia.

Compared with the past, however, and as a direct result of our tragic involvement in Vietnam, the extent of our commitment has been drastically reduced in two of the three cases. In late 1978, when the United States established normal diplomatic relations with Peking, we simultaneously announced the withdrawal of our remaining military forces from Taiwan and the termination of our mutual security treaty with the island. Four years later, in August 1982, we reached an agreement with Peking that we would gradually reduce the quantity of weapons sold to Taiwan, and would not exceed the quality of the arms that were provided to Taipei at the time of the normalization of Sino-American relations. Our role in the conflict in Cambodia is even more indirect. Although we give the Democratic Kampuchean coalition our firm diplomatic support, there are no American forces or advisers involved in the fighting, and the United States provides only a small amount of financial and material aid to the struggle against the Vietnamese and their clients in Phnom Penh.

Only in South Korea is the United States still involved in a sizeable and direct fashion in a regional conflict in East Asia. Even there, however, the number of American troops is now considerably less than it was fifteen years ago. Moreover, as has already been indicated, it is highly likely that Seoul will be asked to make a greater financial contribution to defray American expenses, and even that the level of American deployment will further decline as South Korea's strength and prosperity grows.

Of equal importance is the change in the nature of American participation in the processes of tension reduction and conflict resolution in all these disputes. In the past, the United States was centrally involved in the Panmunjom negotiations along the demilitarized zone in Korea, in the Geneva-Warsaw talks over a renunciation of force in the Taiwan Straits, and in the Paris negotiations over the end of the conflict in Vietnam. In all cases, moreover, Washington dominated the negotiating agenda, with our allies either taking a relatively minor role in the discussions (as in the case of South 
Korea and Vietnam), or absent from the table altogether (as in the case of Taiwan). Today, in contrast, the United States has placed its emphasis on facilitating a process of negotiation and dialogue between the parties immediately concerned, with Washington taking a secondary but reinforcing role.

Thus, with regard to Taiwan, the United States has consistently repeated ever since signing the Shanghai Communiqué in 1972 that the Taiwan question can only be resolved by the Chinese themselves. As Secretary of State George Shultz pointed out in his visit to Shanghai in 1987, the United States hopes to create an environment that will foster contacts between the two sides, and welcomes the growing economic, academic, and humanitarian ties across the Taiwan Straits. Indeed, a good deal of the communication between the scholarly communities of Taiwan and the Mainland occurs in universities and research institutions in the United States. At the same time, however, Washington has also reiterated that it will not serve as a mediator or an intermediary in the dialogue, nor will it endorse either party's negotiating position. Instead, we believe that a peaceful resolution of the Taiwan issue can only come through a natural process of convergence and dialogue between Taipei and Peking.

In Korea the United States also places its emphasis on a direct North-South dialogue over such specific issues as the reunification of divided families, the expansion of economic and cultural exchanges between the two sides, and the development of effective confidence-building mechanisms along the demilitarized zone. The United States is willing to forge contacts with North Korean diplomats and scholars and, under appropriate circumstances, develop economic relations with Pyongyang. We also hope that the Soviet Union and China will develop similar ties with South Korea. Over the longer term, the United States could even contemplate a quadripartite international conference, including representatives from the United States and China, as well as from both Koreas, to discuss the Korean question. But we believe that it ultimately will be the direct North-South dialogue, not any international negotiations or contacts, that will be the key to a meaningful reduction of tension on the Korean peninsula. Indeed, we have made it clear that the United States will improve its relations with North Korea only on the basis of progress in the dialogue between Pyongyang and Seoul.

Similarly, Washington encourages the Association of Southeast Asian Countries (ASEAN) and the Cambodian resistance to take the lead in defining a strategy for negotiations with Hanoi and Phnom Penh for the 
removal of Vietnamese forces from Cambodia. The United States hopes to help create an environment that will encourage Hanoi to moderate its ambitions in Indochina. Accordingly, we provide diplomatic and material support to the Democratic Kampuchean resistance, maintain our security treaty with Thailand, and engage in regular consultations with ASEAN and China over a common strategy toward Cambodia. But we do not believe that a more direct form of American involvement would be conducive to an effective solution of the Cambodian problem, or would secure the support of the American people.

Thus, as it has for more than thirty-five years, the United States retains an interest in the regional disputes in Korea, Taiwan, and Indochina. But the American participation has in most cases become less direct, and focuses on fostering a climate in which the parties directly concerned can work out their solutions through dialogue and negotiation. The United States increasingly recognizes that the strategy for managing and resolving regional disputes must come from the inside out, not from the outside in. We believe that such an approach is more effective and sustainable than a more direct American involvement. Even so, we must also recognize that none of the three disputes in question has yet secured a final resolution.

\section{Political liberalization}

Idealism has long been an important feature of American foreign policy. The United States is, after all, a society born more than two hundred years ago through a violent revolution against a colonial power. Like many postrevolutionary societies, Americans have been convinced of the attractiveness of the values and institutions that guided their revolutionary struggle, and have often sought to export their vision of a just society to other nations.

In postwar Asia, this aspect of American policy has passed through three stages. For the first thirty years following the conclusion of World War II, until the beginning of the Carter Administration, American idealism took the form of vigorous anti-Communism. The United States placed itself in opposition to the emergence of Communist systems throughout the region, whether essentially indigenous (as in China and North Vietnam), or exported by force (as on the Korean peninsula, South Vietnam, or elsewhere in Southeast Asia). Unfortunately, whether in South Korea, the Philippines, or South Vietnam, this formula often led the United States to support 
authoritarian regimes which declared themselves to be pro-Western and anti-Communist, and to expect or demand little in the way of political liberalization.

During the Carter Administration, the shortcomings of earlier policies led to a marked change in emphasis. The United States adopted the goal of protecting and fostering human rights in a wide range of countries, from the totalitarian regimes of the Communist bloc to the authoritarian systems allied with the West. The focus was largely, although not exclusively, on the fate of individual dissidents and protest organizations. In the Asia-Pacific region, the most notable example of the orientation of the Carter Administration was its concern with the fate of Kim Dae-jung following his kidnapping from Japan and his forcible return to South Korea.

The Reagan Administration has not abandoned its predecessor's concern with human rights, but has taken a more systemic approach to the problem. Although it did secure the release of Kim Dae-jung in early 1981, it has paid less attention to the fate of individual dissidents, and has placed greater emphasis on encouraging the peaceful and orderly evolution of Asian political systems in the direction of greater liberalization. Thus, the Reagan Administration has encouraged constitutional reform and a peaceful transition of power in South Korea, the relaxation of political restrictions in Taiwan, and fair and free elections at the end of the Marcos era in the Philippines.

This policy has scored some notable successes. The United States eased the removal of Ferdinand Marcos from the presidency of the Philippines, and arranged for a comfortable exile in Hawaii. American encouragement has helped promote a significant degree of liberalization in Taiwan, with the cancellation of martial law and the end of the legal prohibition on the formation of opposition political parties. In South Korea, pressure from Washington was also instrumental in persuading Chun Doo-hwan to agree to step down at the end of his seven-year term, and in convincing Roh Taewoo to accept the opposition's demand for direct presidential elections at the end of 1987.

Still, the political situation in all three countries remains fragile. Corazon Aquino has proven less effective as president of the Philippines than she was as leader of the anti-Marcos opposition, and is making only gradual progress in her efforts to gain the support of the military and to subdue the Communist insurrection. In South Korea, the elections of late 1987 and early 1988 produced a sharp cleavage between the executive branch controlled by 
the Democratic Justice Party, and the National Assembly, controlled by the opposition. Moreover, violent student protests against the government and against the large American presence in the country continue. On Taiwan, the opposition Democratic Progressive Party has flirted with the concepts of independence and self-determination for the island, and has intensified its calls for a more rapid reform of the country's anachronistic political system. All these developments suggest that the United States will now have to cope with the problems that inevitably arise in authoritarian systems after they have embarked on a course of liberalization and reform. Increasingly, the issue for America may be less how to cope with brutal tyrants than how to deal with ineffective democrats.

Moreover, the United States has not yet defined a clear policy for promoting political liberalization in friendly Communist countries, such as China. The recent visit of the Dalai Lama, and the subsequent riots in Tibet, dramatically revealed the differences between the Reagan Administration and the Congress over the strategy to take toward the question of human rights in China. The Administration's position was that the situation in China is generally improving, and that any overt American pressure would be ineffective at best and counterproductive at worst. Many in Congress, in contrast, insisted that the Chinese record on human rights is not yet satisfactory, and maintained that Peking should be subjected to the same pressure as are other friendly Asian nations. This debate revealed, once again, one of the fundamental dilemmas about the idealistic impulse in American foreign policy: it is virtually impossible to apply general values and principles in international relations in a proportionate and consistent way. Often, it is the weaker allies of the United States, as well as its most committed adversaries, that are the target of American pressure for political reform, while powerful nations that Washington is seeking to cultivate may be relatively immune from criticism.

\section{Economic relations}

The fourth constant element in American policy towards East Asia since World War II has been the desire to promote the economic prosperity of the region, and to build mutually beneficial relations between American and Asian markets. For most of the postwar era, the United States contributed to the development of East Asian economies by aiding friendly nations with 
their security requirements, providing economic and technical assistance, facilitating direct American foreign investment in the Asia-Pacific region, and, above all, by maintaining a relatively open American market that could absorb the output of the dynamic export-oriented economies of the region.

There has been in recent years a fundamental transformation of the character of the American economy and in the pattern of its interactions with the Asia-Pacific region. The basic problem in the United States has been that consumption has exceeded output, investment has exceeded savings, and government expenditures have exceeded government revenues. The result has been a massive inflow of both foreign goods (to satisfy the excess demand for consumption) and foreign capital (to make up for the shortage of domestic savings and taxes). The inflow of foreign merchandise and finance has been expressed in mounting trade deficits, amounting to nearly $\$ 170$ billion in 1986. Moreover, in recent years, the United States has experienced trade imbalances not only with Japan, but also with virtually every other country in East Asia, including some with whom it has traditionally run trade surpluses. Indeed, our trade deficits with the Asia-Pacific region now constitute more than half of our national total.

The imbalance in the American current accounts has stimulated a series of responses over time, each of which has tended to supplement, rather than completely to supersede, earlier approaches. First, there has been classic protectionism. whether expressed in quotas on textiles, "orderly marketing agreements" on automobiles or electronic equipment, proposals for local content requirements or the calls for punitive tariffs against those countries that do not reduce their "unreasonable" trade surpluses with the United States.

Second, the United States has engaged in what might be described as offensive liberalization: using the negotiating power of the American government to open foreign markets to American goods or to gain protection for American intellectual property. Examples include the negotiations with Japan over the export of American automobile parts, telephonic equipment, and construction services; with South Korea over insurance and the protection of patents for chemical production processes; and with Taiwan over the export of American beer, tobacco, and poultry. Like classic protectionism, offensive liberalization may involve the imposition of retaliatory measures against foreign trading partners if negotiations do not achieve the desired results, but its aim is more to open overseas markets to 
American exports rather than to close American markets to foreign products.

Most recently, the Reagan Administration has attempted to employ a policy of negotiated structural adjustment. This strategy involves efforts, again through bilateral negotiations, to reduce the trade imbalance by securing changes in the macroeconomic policies of major American trading partners. Thus, Washington has placed considerable pressure on Japan, South Korea, and Taiwan to revalue their currencies relative to the dollar, and has encouraged Japan to stimulate domestic demand so as to increase internal consumption of Japanese goods and to expand the market for foreign imports. Indeed, the United States has also begun discussions with Tokyo to encourage greater construction of housing, as a way of absorbing the excess domestic savings which are regarded as one of the fundamental causes of Japan's massive and chronic trade surpluses.

The severity of the American economic problem, and the priority assigned by the United States government to combatting them, has placed economic issues on the top of the agenda in American relations with virtually every nation in the Asia-Pacific region. The result has been considerable resentment on the part of American trading partners in East Asia. In part this is because the open American markets to which most nations had become accustomed are now closing somewhat due to the sluggish pace of economic growth and the rise of protectionist sentiment in the United States. In part, too, the economic tensions between America and its Asian trading partners are due to the widespread and correct perception that the United States has been slow to address that part of the problem for which it bears the principal responsibility: the slow growth in domestic productivity and the chronic deficits in the budget of the American government. In addition, as the United States begins to experiment with the strategies which above have been described as offensive liberalization and structural adjustment, it will begin to press its trading partners to alter the character of their domestic economies in ways that will predictably be interpreted as American interference in other nations' internal affairs.

Unless the Reagan Administration can, in its waning months, find the political will to address these underlying difficulties more effectively, or unless that task can be undertaken quickly by the new administration that will take power in January 1989, the prospects are for continuing tensions between the United States and the nations of the Asia-Pacific region over economic issues. Moreover, as the collapse of the American stock markets in 
October 1987 demonstrated, there is still the danger of a recession in the United States that would have the most serious implications for the exportoriented economies of East Asia that are still dependent on the American marketplace for their prosperity and growth.

\section{Conclusion}

This review of the past forty years has suggested the significant changes in the strategies by which the United States has pursued its major objectives in the Asia-Pacific region. The containment of Soviet allies has been replaced by the more direct containment of the Soviet Union itself. American involvement in regional disputes in Korea, Taiwan, and Indochina has become less direct, with Washington now emphasizing the importance of dialogue and negotiation among the parties immediately concerned. The idealistic component in American policy toward East Asia has been transformed from mere anti-Communism to a broader interest in human rights, and from a focus on political dissidents to a concern with the general process of political liberalization. And the sluggish growth of the American economy has led to a resurgence of economic nationalism in the United States, and experimentation with different strategies for remedying the chronic trade deficits which the United States has experienced for the past several years.

Beyond these changes, three further transformations in American strategy toward East Asia require at least a brief mention. First, there has been a change in the relative importance of the enduring American goals and objectives in the Asia-Pacific region. Although the United States retains its traditional interests in maintaining an effective balance of power against the Soviet Union, in deterring the outbreak or escalation of conflict in the regional disputes in which it has been involved, and in promoting political liberalization throughout the region, it is now economic issues that tend to dominate American policy toward East Asia as a whole, as well as toward particular countries within the Asia-Pacific region.

Second, with the extraordinary economic dynamism of the East Asian economies, and with the growing emphasis paid to the Far East in Soviet foreign policy, it is increasingly apparent that the Asia-Pacific region is now, along with Europe, one of the two central foci of American foreign policy. This is not to say that East Asia has now gained primacy over Europe in the 
eyes of American policymakers, nor that it is likely to do so in the near future. The strategic competition between the Soviet Union and the United States remains focussed in Europe, and the European Community contains several of the most important actors in the global economy. But it is true that American foreign policy can no longer be characterized by an Atlantic bias. Instead, it must give at least equal weight to the concerns of the Asia-Pacific nations as well.

Finally, one is struck by the gradual decline of Europe as a factor in American policy toward East Asia. In the immediate postwar period, European nations played a significant role in shaping American relations with the Asia-Pacific region. The views of Great Britain were influential, although not always determinant, in the consideration of American policy toward China and Taiwan. French policy played its role in shaping the American involvement in Indochina. Today, however, the United States chooses its policy toward East Asia without significant regard to the views of its European allies, if only because they have long since ceased to be significant actors in the strategic balance in the Asia-Pacific region. Indeed, the evolution of the Soviet-American negotiations over the reduction of intermediate-range nuclear forces suggests that Asia may now influence American policy toward Europe more than the reverse.

Looking ahead, it is now possible to foresee the gradual end of the postwar era, characterizèd as it was by American dominance of the world economy and the bipolar character of the global strategic balance. In its place is slowly emerging a new international system, that will most likely include a more multipolar structure in both the global economy and in international strategic matters. In the past, such a transformation from one international system to another was usually marked by a global war. Fortunately, the balance of nuclear terror virtually guarantees that the coming change in the international system will occur through a more peaceful and more protracted process. The transformation will not take place in any single cataclysmic event, but rather through the cumulative impact of more subtle but equally significant changes. In retrospect, we may well conclude that we have already witnessed several of them, including China's declaration of an independent foreign policy in 1982, Gorbachev's rise to power in the Soviet Union in 1985, the emergence of the United States as a net debtor nation in 1986-87, and the Japanese decision to expand its defence spending beyond one percent of its GNP in 1987.

These developments present the United States with at least three major 
challenges and opportunities in the Asia-Pacific region over the rest of the century and beyond. First, the growing intensity and complexity of economic relations in East Asia has created a need for greater consultation and coordination in economic matters. The era of American dominance of the global and regional economy is over, but no other nation, not even Japan, is rising to take the place of the United States. Nor is it likely that the nations of the Asia-Pacific region, given the diversity of their economic and political systems, can create a formal Pacific Community, comparable to that which hás been developed in Western Europe. Instead, the challenge will be for the United States and Japan to cooperate in maintaining an open and prosperous East Asian regional economy, with other strong economies increasingly involved in making key decisions.

Second, the greater strategic multipolarity of the region will also create a need for a more complex American military and diplomatic strategy in East Asia. In the past, American strategy was based on the assumption of a bipolar world, in which a single adversary, the Soviet Union, posed the principal threat to the security of the region, and where the best approach for coping with Soviet expansion was to increase the military power of all those who might be willing to cooperate in containing it. In contrast, a multipolar approach to Asia would imply that other countries than the Soviet Union, such as China and Japan, might well be destabilizing forces in the future, and that a sudden and significant increase in the power of any nation in the region might well be disruptive to the balance of power. Relatedly, while a bipolar view of Asia would suggest the maintenance of a network of anti-Soviet alliances, a multipolar approach to the region is more likely to entail a complex and shifting pattern of informal, temporary alignments rather than permanent security obligations.

Finally, the economic dynamism of the Asia-Pacific region may well be a major catalyst for reform in a number of Communist systems. Already, China has embarked on what Deng Xiaoping has described as its second Communist revolution, broadening the range of its foreign economic relationships, increasing the role of market forces and individual initiative in its domestic economy, and taking an active role in most major international economic institutions. At the same time, the priority that Peking now assigns to economic modernization and reform has been accompanied by a significant reorientation of its foreign policy, in the direction of increased pragmatism, more flexibility, and a greater desire for peaceful relations with most of its Asian neighbors. 
Signs of change are now evident in other Asian Communist nations as well. Vietnam and Mongolia are already experimenting with limited forms of economic restructuring, and it is at least conceivable that North Korea will follow a similar course after the death of Kim Il-song. Most importantly, the Soviet Union under Mikhail Gorbachev now appears committed to a program of perestroika that may ultimately rival that of the Chinese. This raises the possibility of integrating the Soviet Union more fully into the Asia-Pacific economy, and, even more, the possibility that the Soviet Union will reorient its foreign policy in ways similar to those undertaken by Peking. It also suggests that Vietnam and North Korea may be persuaded to adopt a more conciliatory posture toward their neighbors. Seizing these opportunities in a responsible manner, with full awareness of the uncertainties that accompany them, will be one of the most important tasks for the United States and its friends in East Asia as we approach the twenty-first century.

Harry Harding is Senior Fellow, Foreign Policy Studies Program, The Brookings Institution. 